Jurnal Penelitian dan Karya Ilmiah

\title{
BOUNDED RATIONAL DALAM PEMBIAYAAN BANK SYARIAH: KAJIAN TERHADAP MASALAH KEAGENAN DALAM PENYALURAN PEMBIAYAAN SYARIAH
}

\author{
${ }^{1}$ Ria Kurniawati \\ 1 Universitas Islam Syekh Yusuf, Kota Tangerang/Negara Indonesia \\ Email:rkurniawati@unis.ac.id
}

\begin{abstract}
Karakteristik dasar bank syariah adalah skemanya berupa profit and loss sharing (PLS) yang diimplementasikan melalui akad mudharabah dan musyarakah. Ciri khusus dalam skema ini memungkinkan bank syariah meminjamkan dalam jangka panjang dengan profil risiko dan tingkat imbal hasil yang lebih tinggi. Namun demikian, total pembiayaan syariah dengan prinsip bagi hasil tidak pernah lebih dari setengah total pembiayaan dengan prinsip jual beli. Meskipun tingkat imbal hasil pembiayaan dengan prinsip bagi hasil lebih tinggi daripada pembiayaan dengan prinsip jual beli. Tujuan penelitian ini adalah mengklasifikasikan dan menganalisis rasional terbatas Bank Umum Syariah di Indonesia. Hasil pengujian menggunakan analisis klaster didapatkan tujuh bank masuk ke dalam kelompok bank yang rasional terbatas dan hanya terdapat satu bank yang masuk ke dalam kelompok rasional. Secara keseluruhan, adanya informasi asimetri dapat memunculkan ketegangan atau konflik kepentingan antara bank dan nasabah yang disebut dengan masalah keagenan.
\end{abstract}

Keywords: bounded rational, agency problem, mudharabah, musyarakah, murabahah

74|Pelita - Jurnal Penelitian dan Karya Ilmiah 


\section{A. Pendahuluan}

Karakteristik dasar bank syariah adalah skemanya berupa profit and loss sharing (PLS) yang diimplementasikan melalui akad mudharabah dan musyarakah (Huda 2012). Akad mudharabah berbentuk kerjasama usaha antar dua pihak dimana pihak pertama (shahibul mal) menyediakan seluruh $(100 \%)$ modal, sedangkan pihak lainnya sebagai pengelola. Keuntungan dibagi berdasarkan kesepakatan yang dituangkan dalam kontrak dan bila terjadi kerugian maka ditanggung oleh pemilik modal selama kerugian itu bukan akibat kelalaian pengelola (Amaroh 2013). Sedangkan akad musyarakah merupakan bentuk akad kerja sama antara dua pihak atau lebih untuk suatu usaha tertentu dimana masing-masing pihak memberikan kontribusi dana dengan kesepakatan bahwa keuntungan dan risiko akan ditanggung bersama sesuai kesepakatan (Amaroh 2013). Berdasarkan definisi tersebut, ciri khusus dalam skema ini memungkinkan bank syariah untuk meminjamkan dana dalam jangka panjang dengan profil risiko dan tingkat imbal hasil yang lebih tinggi. Namun demikian, total pembiayaan syariah dengan prinsip bagi hasil tidak pernah lebih dari setengah total pembiayaan dengan prinsip jual beli (Rimadhani dan Erza 2011; Prasetyo 2013). Hal ini dapat dilihat dari statistik alokasi pembiayaan murabahah yang mendominasi tiap tahunnya. Pada tahun 2014 mencapai 58,88\% lebih besar dari akad mudharabah dan musyarakah yang hanya mencapai 7,2\% dan 21,02\% (Gambar 1).

Data tersebut menunjukkan bahwa pembiayaan produk dengan prinsip jual beli, yaitu murabahah mendominasi pembiayaan dalam perbankan syariah di Indonesia. Hal ini dikarenakan murabahah adalah pembiayaan yang memiliki risiko paling kecil dari sisi risiko kredit, risiko mark-up, risiko likuiditas, maupun risiko operasional (Mutmainah dan Chasanah 2012). Dengan demikian, bank syariah lebih menyukai pembiayaan produk jenis ini (Simorangkir 2014).

Meskipun pembiayaan dengan akad murabahah mendominasi pembiayaan pada bank syariah, tingkat imbal hasil terbesar justru terdapat pada pembiayaan dengan akad mudharabah (prinsip bagi hasil). Hal ini dapat dilihat dari statistik tingkat imbal hasil akad mudharabah yang mencapai 20,69\% pada tahun 2014 lebih besar dari tingkat imbal imbal hasil akad murabahah dan akad musyarakah yang hanya mencapai $15,43 \%$ dan 13,53\%. (Gambar 1). Hal ini sejalan dengan penelitian yang dilakukan oleh Wibowo dan Hardiwinoto (2014) dan Handayani (2012) yang menyebutkan bahwa sistem bagi hasil sangat

75|Pelita - Jurnal Penelitian dan Karya Ilmiah 
menguntungkan dan sejalan dengan tujuan dan kepentingan bisnis yang dijalankan serta berpotensi memberikan keuntungan yang tinggi bagi bank syariah. Dengan demikian, tidak heran jika pembiayaan pada akad bagi hasil (mudharabah) memiliki tingkat imbal hasil yang paling

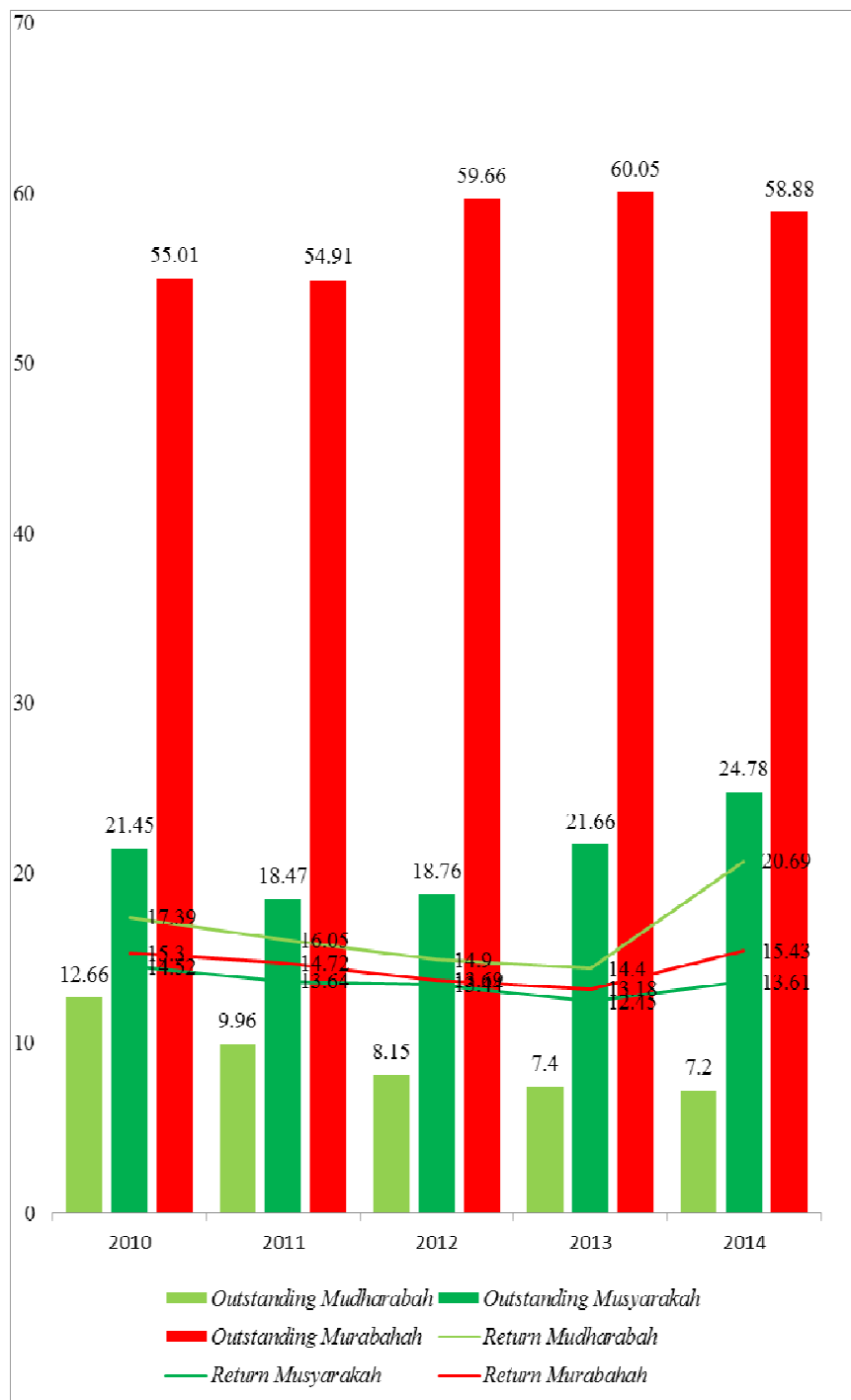

tinggi dibandingkan dengan jenis pembiayaan lainnya.

Gambar 1 Alokasi pembiayaan dan tingkat imbal hasil Bank Umum Syariah (BUS) dan Unit Usaha Syariah (UUS) di Indonesia (\%) 
Meskipun pembiayaan bagi hasil memiliki tingkat imbal hasil yang tinggi dan sekaligus merupakan karakteristik dasar bank syariah dan pembeda dengan bank konvensional (Antonio 2001), nyatanya pembiayaan bagi hasil masih belum mampu mendominasi portfolio perbankan syariah di Indonesia. Hal ini dikarenakan pembiayaan bagi hasil (mudharabah dan musyarakah) memiliki tingkat risiko yang paling tinggi (Mutmainah dan Chasanah 2012). Selain itu, bank syariah memberikan batasan-batasan dalam bisnis keuangan (El-Hawary et al 2007). Pertama, risk sharing dalam transaksi keuangan berkaitan risiko dan tingkat hasil simetri bagi tiap pihak dalam setiap transaksi. Kedua, materialitas dalam transaksi keuangan harus memiliki hubungan secara langsung maupun tidak langsung dengan transaksi ekonomi riil. Ketiga, tidak ada eksploitasi antar berbagai pihak dalam transaksi keuangan, dan keempat, tidak ada pembiayaan pada proyek atau kegiatan yang memproduksi barang-barang yang diharamkan dalam Islam. Selain batasan-batasan yang telah disebutkan sebelumnya, bank syariah juga harus bebas dari riba. Bank syariah harus menjalankan transaksi yang bebas dari ketidakpastian (gharar), perjudian (gambling), dan kegiatan-kegiatan yang tidak halal (Aris 2010). Dasar-dasar tersebut sebagai bentuk tanggung jawab sosial dan etika bank yang akhirnya menyebabkan bank syariah berperilaku rasional terbatas.

\section{B. Metode}

Penelitian ini dilakukan pada delapan BUS yang ada di Indonesia dengan periode waktu penelitian tahun 2011-2015. Jenis data yang digunakan dalam penelitian ini adalah data sekunder, yaitu laporan keuangan tahunan BUS periode tahun 2011-2015. Teknik pengambilan sampel yang digunakan dalam penelitian ini adalah purposive sampling, yang merupakan metode pengambilan sampel berdasarkan beberapa kriteria, yaitu:

1. BUS yang mempublikasikan laporan keuangan tahunan selama periode 2011-2015.

2. BUS yang memiliki kelengkapan data berdasarkan variabel yang diteliti. Adapun variabel yang diteliti dalam penelitian ini adalah risiko yang ditunjukkan pada NPF dan tingkat imbal hasil

Berdasarkan kriteria di atas, didapatkan delapan BUS yang dijadikan sampel, yaitu:

77|Pelita - Jurnal Penelitian dan Karya Ilmiah 
1. PT. Bank Muamalat Indonesia (BMI)

2. PT. Bank Syariah Mandiri (BSM)

3. PT. Bank Syariah Mega Indonesia (BSMI)

4. PT. Bank BRI Syariah (BRIS)

5. PT. Bank Syariah Bukopin (BUKOPINS)

6. PT. Bank BNI Syariah (BNIS)

7. PT. Bank Panin Syariah (PANINS)

8. PT. BCA Syariah (BCAS)

Data yang diperoleh dianalisis menggunakan microsoft excel dan Statistical Package for Social Science (SPSS) versi 23 untuk selanjutnya dilakukan analisis klaster.

\section{Temuan Hasil Penelitian}

Perhitungan analisis klaster dengan menggunakan software SPSS Statistics 23 didapatkan hasil pada tabel 1:

Tabel 1 Final cluster centre

\begin{tabular}{lll}
\hline & \multicolumn{1}{c}{ Klaster-1 } & \multicolumn{1}{c}{ Klaster-2 } \\
\hline Zscore $\left(X_{1}\right)$ & $-0,15969$ & 0,02281 \\
Zscore $\left(X_{2}\right)$ & 2,45232 & $-0,35033$ \\
Zscore $\left(X_{3}\right)$ & 1,73924 & $-0,24846$ \\
Zscore $\left(X_{4}\right)$ & 0,09517 & $-0,01360$ \\
Zscore $\left(X_{5}\right)$ & 0,53244 & $-0,07606$ \\
Zscore $\left(X_{6}\right)$ & 2,37878 & $-0,33983$ \\
\hline
\end{tabular}

${ }^{*} \mathrm{X}_{1}$ : Risiko murabahah, $\mathrm{X}_{2}$ : Risiko mudharabah, $\mathrm{X}_{3}$ : Risiko musyarakah,

$\mathrm{X}_{4}$ : Tingkat Imbal Hasil murabahah, $\mathrm{X}_{5}$ : Tingkat Imbal Hasil mudharabah,

$\mathrm{X}_{6}$ : Tingkat Imbal Hasil musyarakah

Sumber: Data diolah (2016)

Tabel 1 masih terkait dengan proses standarisasi yang mengacu pada nilai $z$-score. Nilai $z$-score tertinggi pada klaster 1 yaitu pada $z$-score $\left(\mathrm{x}_{2}\right)$ yang merupakan nilai $z$-score dari risiko mudharabah sebesar 2,45232. Sedangkan pada klaster 2 nilai $z$-core tertinggi yaitu pada $z$-score $\left(\mathrm{x}_{1}\right)$ yang merupakan nilai $z$-score dari risiko murabahah. Hal ini berarti kedua data berada tersebut berada di atas rata-rata total. 
Perhitungan menggunakan Microsoft Excel 2013 didapatkan hasil pada Tabel 2.

Tabel 2 Rata-rata risiko dan tingkat imbal hasil pada klaster

\begin{tabular}{lcc}
\hline Variabel & Klaster-1 & Klaster-2 \\
\hline Risiko Murabahah & 3,26 & 3,76 \\
Risiko Mudharabah & 39,48 & 1,75 \\
Risiko Musyarakah & 11,20 & 3,88 \\
Return Murabahah & 19,98 & 19,09 \\
Return & 15,38 & 14,29 \\
Mudharabah & & 14,26 \\
Return Musyarakah & 34,53 & \\
\hline
\end{tabular}

Sumber: Data diolah (2016)

Klaster-1: Berisikan bank dengan karakteristik risiko murabahah tinggi, risiko mudharabah tinggi, risiko musyarakah tinggi, tingkat imbal hasil murabahah tinggi, tingkat imbal hasil mudharabah tinggi, dan tingkat imbal hasil musyarakah tinggi.

Klaster-2: Berisikan bank dengan karakteristik risiko murabahah tinggi, risiko mudharabah rendah, risiko musyarakah tinggi, tingkat imbal hasil murabahah tinggi, tingkat imbal hasil mudharabah tinggi, dan tingkat imbal hasil musyarakah tinggi.

Berdasarkan teori portofolio investasi, dimana hubungan antara risiko dan tingkat imbal hasil adalah linier dan searah, artinya semakin besar tingkat imbal yang diharapkan, maka semakin besar pula risiko yang harus ditanggung (Prabowo 2009). Pembiayaan dikatakan rasional yaitu apabila terjadi risiko dan tingkat imbal hasil simetri (Amaroh 2013). Dengan demikian, penamaan masing-masing klaster ditentukan sebagai berikut: 
- Rasional, jika hubungan antara risiko dan tingkat imbal hasil adalah linier, yaitu risiko tinggi dengan tingkat imbal hasil tinggi atau risiko rendah dengan tingkat imbal hasil rendah.

- Rasional terbatas, jika hubungan risiko dan tingkat imbal hasil asimetri, yaitu risiko tinggi dengan tingkat imbal hasil rendah atau risiko rendah dengan tingkat imbal hasil tinggi.

Berdasarkan ketentuan di atas, dapat dilihat bahwa terdapat asimetri antara risiko dan tingkat imbal hasil pada klaster 2, yaitu risiko rendah yang terdapat pada akad mudharabah justru menghasilkan tingkat imbal hasil yang tinggi pada akad pembiayaan tersebut. Dengan demikian, dapat disimpulkan bahwa klaster-1 merupakan bank dengan karakteristik rasional dan klaster-2 merupakan bank dengan karakteristik rasional terbatas. Masing-masing anggota klaster dapat dilihat pada Tabel 3 .

Tabel 3 Anggota masing-masing klaster

\begin{tabular}{cccc}
\hline No & BUS & Klaster & Jarak \\
\hline 1 & BSM & 2 & 1,339 \\
2 & BMI & 2 & 1,397 \\
3 & BCAS & 2 & 1,722 \\
4 & BNIS & 2 & 1,688 \\
5 & BRIS & 2 & 2,587 \\
6 & BUKOPINS & 2 & 2,490 \\
7 & BSMI & 1 & 0,000 \\
8 & PANINS & 2 & 1,545 \\
\hline
\end{tabular}

Sumber: Data diolah (2016)

Berdasarkan tabel 3, terlihat jelas klaster-1 hanya beranggotakan satu bank yaitu PT. Bank Syariah Mega Indonesia, dan klaster-2 beranggotakan tujuh bank yaitu, PT. Bank Syariah Mandiri, PT. Bank Muamalat Indonesia, PT. Bank BCA Syariah, PT. Bank BNI Syariah, PT. Bank BRI Syariah, PT. Bank Syariah Bukopin, dan PT. Bank Panin Syariah. 


\section{Diskusi}

Rendahnya alokasi pada akad mudharabah diakibatkan adanya perilaku rasional terbatas BUS dalam menilai nasabahnya. BUS tidak dapat menilai satu per satu nasabah yang datang. Sebagai akibatnya, BUS dibebankan pada nasabah yang kurang jujur. Dengan demikian, BUS menetapkan tingkat marjin yang tinggi pada pembiayaannya agar tetap mendapatkan manajemen laba bagi perusahaan. Akibatnya terjadi ketidakseimbangan informasi antara BUS dan nasabah yang menyebabkan informasi asimetri. Informasi asimetri ini yang kemudian dapat menimbulkan masalah keagenan antara bank dan nasabah.

Masalah keagenan muncul akibat informasi asimetri antara bank dan nasabah. Asumsinya adalah bank lebih banyak memiliki informasi daripada nasabah. Akibatnya, nasabah tidak bisa menolak meskipun dibebankan dengan marjin yang tinggi oleh bank. Pembebanan tingkat marjin yang tinggi pada nasabah ini mengakibatkan pembiayaan di BUS tidak terdapat adanya suatu keadilan, seperti yang dijadikan tujuan BUS.

Secara keseluruhan hasil penelitian ini memberikan implikasi pada terdapatnya adverse selection sebagai akibat adanya pembebanan marjin yang tinggi bagi nasabah dan perilaku rasional terbatas sebagai akibat risiko dan tingkat imbal hasil yang asimetri pada setiap jenis pembiayaan di BUS.

\section{E. Kesimpulan (Conclusion)}

Berdasarkan hasil analisis yang telah dilakukan, maka penelitian ini memberikan kesimpulan bahwa terdapat tujuh BUS berperilaku rasional terbatas yaitu, PT. Bank Muamalat Indonesia, PT. Bank Syariah Mandiri, PT. Bank BRI Syariah, PT. Bank Syariah Bukopin, PT. Bank BNI Syariah, PT. Bank Panin Syariah, dan PT. Bank BCA Syariah. Sedangkan hanya terdapat satu bank yang berperilaku rasional yaitu PT. Bank Syariah Mega Indonesia. Berdasarkan akad pembiayaannya, bank-bank yang termasuk kedalam bank yang rasional terbatas menurut akad murabahah adalah PT. Bank BCA Syariah, PT. Bank BNI Syariah, dan PT. Bank Panin Syariah. Pada akad mudharabah adalah PT. Bank BRI Syariah, PT. Bank BCA Syariah, PT. Bank Panin Syariah, PT. Bank Syariah Bukopin, dan PT. Bank BNI Syariah. Pada akad musyarakah PT. Bank BCA Syariah, PT. Bank BNI Syariah, PT. Bank BRI Syariah, PT. Bank Syariah Bukopin, dan PT. Bank Panin Syariah.

81|Pelita - Jurnal Penelitian dan Karya Ilmiah 
Sedangkan bank yang termasuk kedalam kelompok rasional berdasarkan akad pembiayaannya adalah PT. Bank Muamalat Indonesia, PT. Bank Syariah Mandiri, dan PT. Bank Syariah Mega Indonesia.

\section{Referensi}

Amaroh, S. 2013. Perbandingan Imbal Hasil Kontrak Mudharabah dan Partisipasi Modal dalam Penghimpunan Dana Bank Syariah Indonesia. Inferensi Jurnal Penelitian Sosial Keagamaan. Vol 7(1). 231254. [diunduh Maret 7]. Tersedia pada: https://www.academia.edu/16727369/PERBANDINGAN_IMBA L_HASIL_KONTRAK_MUDHARABAH_DAN_PARTISIPASI_MO DAL_DALAM_PENGHIMPUNAN_DANA_BANK_SYARIAH_DI INDONESIA.

Antonio MS. 2001. Bank Syariah: dari Teori ke Praktek. Jakarta (ID): Gema Insani Press.

Aris, RT. 2010. Competitive Conditions in Islamic and Conventional Banking: A Global Perspective. Revieuw of Financial Economic.

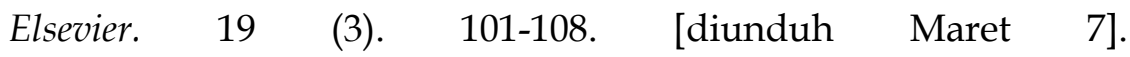
http://www.sciencedirect.com/science/article/pii/S1058330010 $\underline{000066}$

Bank Bukopin Syariah. Laporan Keuangan Tahunan 2011-2015. [diunduh 2016 Juli 21]. Tersedia pada: http://www.syariahbukopin.co.id/id/laporan

Bank Indonesia. Statistik Perbankan Syariah 2010-2014. [diunduh 2016 Maret 3]. Tersedia pada: http://www.bi.go.id/id/statistik/perbankan/syariah/Default.as px

Bank Mega Syariah. Laporan Keuangan Tahunan 2011-2015. [diunduh Juli 26]. Tersedia pada: http://www.megasyariah.co.id/

Bank Muamalat Indonesia. Laporan Keuangan Tahunan 2011-2015. [diunduh Juli 21]. Tersedia pada: http://www.bankmuamalat.co.id/hubungan-investor/laporantahunan 
Bank Panin Syariah. Laporan Keuangan Tahunan 2011-2015. [diunduh Juli 21]. Tersedia pada: https:// www.paninbanksyariah.co.id/index.php/mtentangkami $\angle$ laporantahunan

Bank Syariah Mandiri. Laporan Keuangan Tahunan 2011-2015. [diunduh Juli 23]. Tersedia pada: http://www.syariahmandiri.co.id/category/investorrelation/laporan-tahunan/

BCA Syariah. Laporan Keuangan Tahunan 2011-2015. [diunduh Juli 21]. Tersedia pada: http://www.bcasyariah.co.id/laporankeuangan/tahunan/2015-2/.

BNI Syariah. Laporan Keuangan Tahunan 2011-2015. [diunduh Juli 22]. Tersedia pada: http://www.bnisyariah.co.id/laporan-keuangan

BRI Syariah. Laporan Keuangan Tahunan 2011-2015. [diunduh Juli 22]. Tersedia pada: http://www.brisyariah.co.id/?q=laporantahunan.

El-Hawary D, Grais W, dan Iqbal Z. 2007. Diversity in The Regulationof Islamic Financial Institutions. The Quarterly Revieuw of Economic and Finance. Elsevier. 46 (5). 778-800. [diunduh Maret 7]. Tersedia pada:

http://www.sciencedirect.com/science/article/pii/S10629769060 $\underline{00986 .}$.

Handayani, F. 2012. Pengukuran Risiko Pembiayaan Perbankan Syariah Indonesia (Pendekatan Value At Risk). [Tesis]. Jakarta (ID). Universitas Indonesia. [diunduh Maret 5]. Tersedia pada: https:// www.academia.edu/4705557/PENGUKURAN_RISIKO PEMBIAYAAN_PERBANKAN_SYARIAH_INDONESIA_PENDE KATAN_VALUE_AT_RISK.

Huda, AN. 2012. The Development of Islamic Financing Scheme for SMEs in Developing Country: The Indonesian Case. Elsevier B.V. Procedia. Social and Behavioral Sciences 52 (2012). 179-186. [diunduh April 3]. Tersedia pada: http://www.sciencedirect.com/science/article/pii/S18770428120 $\underline{39092}$

Mutmainah, Chasanah SNZ. 2012. Analisis Eksternal dan Internal dalam Menentukan Non Performing Financing Bank Umum Syariah di Indonesia. Jurnal Bisnis dan Ekonomi (JBE). 19 (1): 49-64. [diunduh April 5]. Tersedia pada: http:// download.portalgaruda.org/article.php?article $=110022 \& \mathrm{~V}$ $\underline{\mathrm{al}=548}$.

83 Pelita - Jurnal Penelitian dan Karya Ilmiah 
Prabowo Y. 2009. Analisis Resiko dan Pengembalian Hasil pada Perbankan Syariah: Aplikasi Metode VaR dan RAROC pada Bank Syariah Mandiri. La_Riba Jurnal Ekonomi Islam. 3(1): 90-105 . [diunduh Maret 7]. Tersedia pada: http://moraref.or.id/record/view/30155.

Prasetyo PA. 2013. Identifikasi Faktor yang Mempengaruhi Rendahnya Pembiayaan Bagi Hasil Perbankan Syariah (Studi Kasus PT. BRI Syariah Kantor Cabang Malang. [Jurnal Ilmiah]. Malang (ID). Universitas Brawijaya. [diunduh Agustus 21]. Tersedia pada: http:// download.portalgaruda.org/article.php?article $=189068 \& \mathrm{v}$ al=6467\&title=IDENTIFIKASI\%20FAKTOR\%20YANG\%20MEMP ENGARUHI\%20RENDAHNYA\%20\%20PEMBIAYAAN\%20BAGI \%20HASIL \%20PERBANKAN\%20SYARIAH \%20\%20(Studi \%20Ka sus \%20Bank\%20BRI\%20Syariah\%20Cabang\%20Malang).

Rimadhani M, Erza O. 2011. Analisis Variabel-Variabel yang Mempengaruhi Pembiayaan Murabahah pada Bank Syariah Mandiri Periode 2008.01-2011.12. Media Ekonomi. 19 (1): 27-52. [diunduh Januari 13]. Tersedia pada: http://www.online.feb.trisakti.ac.id/publikasi_ilmiah/Jurnal\%20 Media \%20Ekonomi/VOL.\%2019\%20NOMOR\%201\%20APRIL\%20 2011/2.pdf

Simorangkir I. 2014. Pengantar Kebanksentralan: Teori dan Praktik di Indonesia. Jakarta (ID): PT Rajagrafindo Persada.

Wibowo RE, Hardiwinoto. 2014. Pemahaman Rasional Pembiayaan Syariah, Relgiutas, Primordialisme Pengusaha dan Pengaruhnya Terhadap Sikap Pengusaha dalam Memilih Pembiayaan di Bank Syariah. Seminar \& Call Paper "Tata Kelola Organisasi dan Arah Pembangunan Ekonomi Indonesia. BENEFIT Jurnal Manajemenb dan Bisnis. 9(1): 45-52. [diunduh Februari 11]. Tersedia pada: journals.ums.ac.id/index.php/benefit/article/download/1410/964. 